\title{
Chemometric Evaluation of the Heavy Metals in Urban Soil of Fallujah City, Iraq
}

\author{
Emad A. Salah" ${ }^{*}$, Ahmed M. Turki², Shemma N. Mahal2 \\ ${ }^{1}$ Department of Applied Geology, University of Anbar, Ramadi, Iraq \\ ${ }^{2}$ Department of Biology, University of Anbar, Ramadi, Iraq \\ Email: "salahemad99@gmail.com
}

Received 20 June 2015; accepted 15 November 2015; published 18 November 2015

Copyright (C) 2015 by authors and Scientific Research Publishing Inc.

This work is licensed under the Creative Commons Attribution International License (CC BY). http://creativecommons.org/licenses/by/4.0/

\section{(c) (i) Open Access}

\begin{abstract}
To evaluate the concentrations of heavy metals and identification of their sources, 20 composite soil samples were collected randomly in Fallujah city, Iraq. To assess the pollution level, we used the soil metal index (SMI) and enrichment factor. We investigated the sources of heavy metal using the chemometric techniques such as correlation analysis, principal component analysis (PCA) and cluster analysis (CA). The concentrations of $\mathrm{Pb}$ and $\mathrm{Co}$ have a normal distribution in soil of the study area. $\mathrm{Zn}$ and $\mathrm{Cd}$ have an approximately normal distribution, and $\mathrm{Ni}, \mathrm{Cu}$, and $\mathrm{Cr}$ have a nonnormal distribution. Our results revealed that the urban soils in Fallujah city were unpolluted by heavy metals and showed a significant to extremely high enrichments of heavy metals controlled by anthropogenic activities. The moderate to strong positive correlations among $\mathrm{Cd}, \mathrm{Co}, \mathrm{Cu}, \mathrm{Cr}, \mathrm{Ni}$, $\mathrm{Pb}$, and $\mathrm{Zn}$ suggest that these metals have common sources. The chemometric techniques identify that the source of $\mathrm{Cu}, \mathrm{Co}$ and $\mathrm{Pb}$ is controlled by lithogenic origin and that the source of $\mathrm{Cr}$, $\mathrm{Ni}$ and Cd is controlled by mixed sources (lithogenic and anthropogenic).
\end{abstract}

\section{Keywords}

Chemometric, Heavy Metal, Urban Soil, Iraq

\section{Introduction}

Urban soil is a soil material having a non-agricultural, man-made surface layer more than $50 \mathrm{~cm}$ thick that has been produced by mixing, filling, or by contamination of land surfaces in urban and suburban areas [1]. Urban soils have peculiar characteristics, such as vertical and spatial variability, unpredictable layering, poor structure, low organic matter content, high content of anthropogenic materials, high concentrations of heavy metals, and

${ }^{*}$ Corresponding author.

How to cite this paper: Salah, E.A., Turki, A.M. and Mahal, S.N. (2015) Chemometric Evaluation of the Heavy Metals in Urban Soil of Fallujah City, Iraq. Journal of Environmental Protection, 6, 1279-1292. http://dx.doi.org/10.4236/jep.2015.611112 
modified soil organisms population and activity [2]-[4]. The urban soil is highly modified by human activities like terrestrials and subterranean constructions, infrastructures reconstructions, the maintenance of parks and green zones, in which the local soil is mixed with soils from other locations [5] [6]. Heavy metals in urban soils have been shown to be very useful tracers of environmental pollution [7]. As heavy metals are non-biodegradable and accumulative in nature, the elevated metal emissions and their deposition over time can lead to anomalous enrichment and the contamination of the surface environment [8]. The most important sources of metal pollution are mine tailings, smelter emissions, waste incineration, atmospheric deposition and traffic emissions [9]-[11]. Due to proximity to humans, accumulation of harmful substances in urban soils is of great concern [12] [13]. Studies on heavy metals in urban soils were carried out in different regions around the world [14]-[24].

Chemometric techniques widely applied in atmospheric studies for identifying sources of pollutants or for determining the importance of contaminant source contributions to a particular site, have been little use in soil studies, but may be effectively employed in such investigations [25]. Chemometric techniques such as correlation analysis, principal component analysis (PCA) and cluster analysis (CA) are employed to identify sources contributing to observing heavy metal pollution of soils [26]-[33].

The aim of this study is to apply the chemometric techniques of correlation analysis, principal component analysis (PCA), and cluster analysis (CA) to evaluate the heavy metal content of urban soil in Fallujah city and identify sources of heavy metal pollution.

\section{Materials and Methods}

Fallujah city located roughly $69 \mathrm{~km}$ west of Baghdad on the Euphrates River, 33²1'13"N, 4346'46"E (Figure 1). The city grew from a small town in 1947 to a population of 326,471 inhabitants in 2010. The region has been inhabited for many millennia. There is evidence that the area surrounding Fallujah is inhabited in Babylonian times. Geologically, Fallujah city is situated on the quaternary unconsolidated sediment of the Mesopotamian plain formed mainly from river sediments (sand, silt and clay).

The sampling sites were randomly distributed in the study area (Figure 1$)$. The soil $(0-0.9 \mathrm{~m})$ was collected. Each of the soil samples consisted of 3 subsamples obtained in different depths $(0-0.3 \mathrm{~m}, 0.3-0.6 \mathrm{~m}$ and 0.6 $0.9 \mathrm{~m}$ ) using a hand auger. Locations of the sampling sites were recorded using Garmon 72 GPS. For each sampling site, a composite sample was made by mixing the three subsamples. The soil samples were kept in plastic bags. They were oven-dried in the laboratory at $105^{\circ} \mathrm{C}$ for $24 \mathrm{~h}$, sieved through a 2-mm stainless steel sieve to remove large debris, gravel-sized materials, plant roots and other waste materials and they were homogenized with porcelain pestle and mortar. Then these samples passed through a 2-mm stainless steel sieve and stored in closed plastic bags until analysis. Soil samples were digested with a 3:2:2 mixture of $\mathrm{HNO}_{3}-\mathrm{H}_{2} \mathrm{SO}_{4}-\mathrm{HCl}$ [34]. The digested solutions were analyzed by Atomic Absorption Spectrometry (AAS Phoenix-986). All of the soil samples were analyzed for their total concentrations of $\mathrm{Cu}, \mathrm{Zn}, \mathrm{Ni}, \mathrm{Pb}, \mathrm{Fe}, \mathrm{Cd}$, Co and $\mathrm{Cr}$. The absolute concentrations of heavy metals in the urban soil of the study area were listed in Table 1.

The soil pollution level and its variation along the sites are determined using soil metal index (SMI). This index is a quick tool to compare the pollution status of different sites. For calculation the SMI for each sampling site, the ratio of heavy metal concentration in the soil sample to the background concentration of the metal is calculated first, for each metal. These values are then summed up and divided with number of metals investigated in this study for the background concentrations are used and multiplied by 100 . The following equation was used to calculate the SMI:

$$
\mathrm{SMI}=\left(C_{1} / B_{1}+C_{2} / B_{2}+C_{3} / B_{3}+\cdots+C_{n} / B_{n}\right) / n
$$

where $C$, in $\mathrm{mg} / \mathrm{kg}$, is the measured concentration of a metal for a particular sampling site; $\boldsymbol{B}$, in $\mathrm{mg} / \mathrm{kg}$, is the background (reference) concentration of a metal; and $n$ is a number of metals ( $n=7$ in this study). Because there are no data about the uncontaminated soils in the study area, we used the Dutch reference concentrations of a metal [35] as background concentrations of metals. These reference concentrations were listed in Table 2. The SMI above $100 \%$ pointed out the polluted soils while the SMI below $100 \%$ indicated the unpolluted soils.

The enrichment factor $(\mathrm{EF})$ of metals is a useful indicator reflecting the status and degree of environmental contamination [36]. The EF calculations compare each value with a given background level, either from the local site, using older soils formed under similar conditions, but without anthropogenic impact, or from a regional or global average composition [37] [38]. The EF was calculated using the method proposed by [39] as follows: 


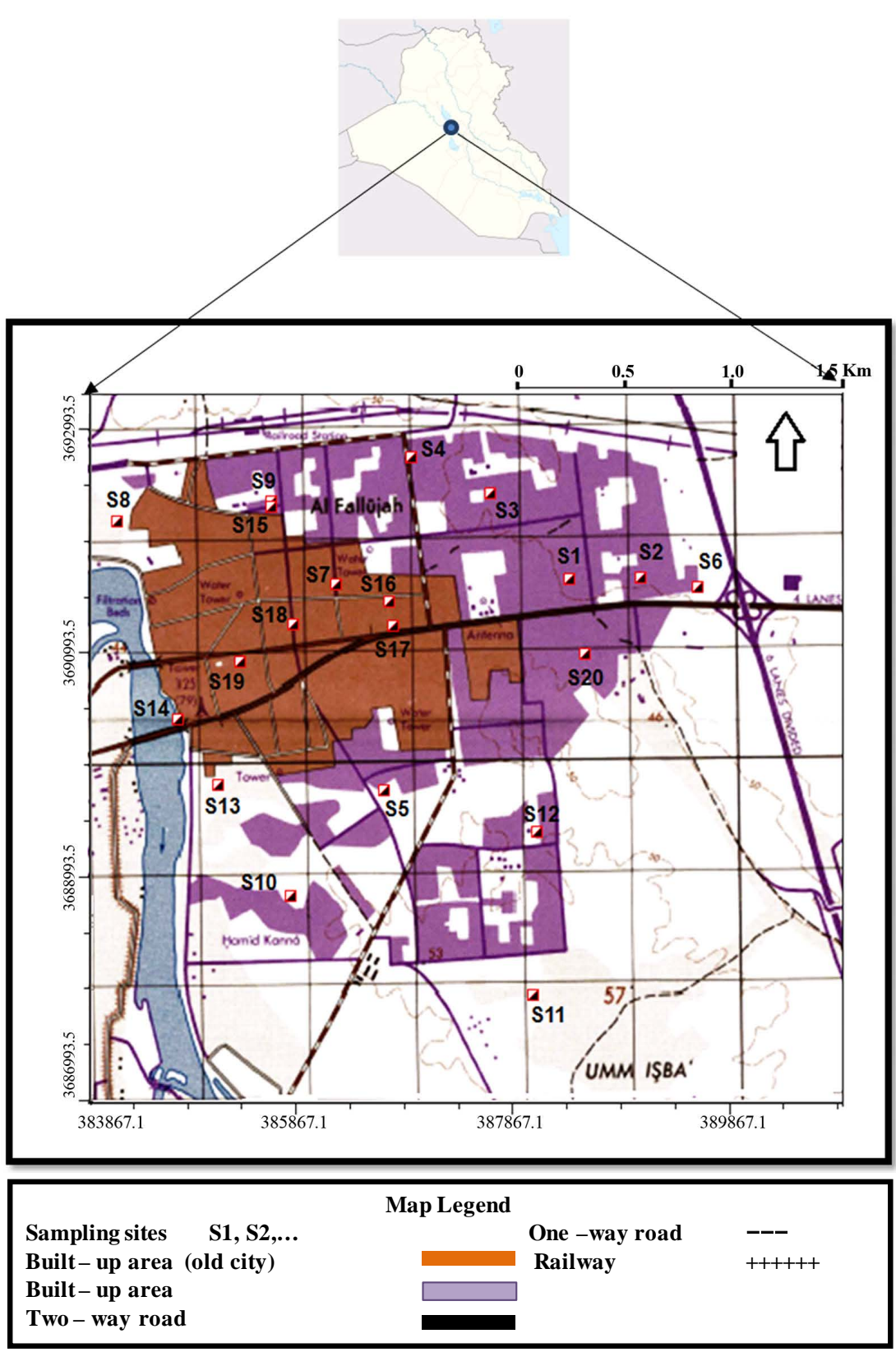

Figure 1. Map of the Fallujah city with location of sampling site of soil (After Salah et al. [22]).

$$
\text { Enrichment Factor }(\mathrm{EF})=\frac{\left(\frac{\mathrm{Me}}{\mathrm{Fe}}\right) \text { sample }}{\left(\frac{\mathrm{Me}}{\mathrm{Fe}}\right) \text { background }}
$$

where $(\mathrm{Me} / \mathrm{Fe})$ sample is the metal to Fe ratio in the sample of interest; $(\mathrm{Me} / \mathrm{Fe})$ background is the natural background value of metal to Fe ratio. As we do not have metal background values for our study area, we used the values from world average data [40]. Iron was chosen as the element of normalization because natural sources (1.5\%) vastly dominate its input [41]. Five contamination categories are recognized on the basis of the enrichment factor, where EF $<2$ is deficiency to minimal enrichment; EF 2 - 5 is moderate enrichment; EF 5 - 20 is significant enrichment; EF 20 - 40 is very enrichment, and EF > 40 is extremely high enrichment [42]. 
Table 1. Concentrations (in $\mathrm{mg} / \mathrm{kg}$ ) of the heavy metals in the sampling sites of the study area.

\begin{tabular}{|c|c|c|c|c|c|c|c|c|c|}
\hline Sampling Site & $\mathrm{Cu}$ & $\mathrm{Zn}$ & $\mathrm{Ni}$ & $\mathrm{Pb}$ & Mn & $\mathrm{Fe}$ & $\mathrm{Cd}$ & Co & $\mathrm{Cr}$ \\
\hline S1 & 2.050 & 8.925 & 12.05 & 4.625 & 25.875 & 417.700 & 0.800 & 3.825 & 21.225 \\
\hline S2 & 0.925 & 3.800 & 5.575 & 3.475 & 10.225 & 296.350 & 0.575 & 2.275 & 12.325 \\
\hline S3 & 1.325 & 5.175 & 10.475 & 4.575 & 21.950 & 332.725 & 0.825 & 3.625 & 14.300 \\
\hline S4 & 1.050 & 5.350 & 10.375 & 3.975 & 22.200 & 352.950 & 0.650 & 3.525 & 16.725 \\
\hline S5 & 1.425 & 6.950 & 10.525 & 3.000 & 20.450 & 275.400 & 0.575 & 3.150 & 14.900 \\
\hline S6 & 1.450 & 3.225 & 6.400 & 3.150 & 18.400 & 201.875 & 0.600 & 2.650 & 9.450 \\
\hline S7 & 0.875 & 4.750 & 8.400 & 2.675 & 27.225 & 189.325 & 0.750 & 3.250 & 11.600 \\
\hline S8 & 1.000 & 6.425 & 7.375 & 2.900 & 21.225 & 205.750 & 0.625 & 3.100 & 11.300 \\
\hline S9 & 1.450 & 4.925 & 7.525 & 2.625 & 22.675 & 203.300 & 0.525 & 2.950 & 10.725 \\
\hline S10 & 1.000 & 2.750 & 6.275 & 2.750 & 13.200 & 209.250 & 0.525 & 2.800 & 9.400 \\
\hline S11 & 1.600 & 3.100 & 7.550 & 3.550 & 16.425 & 215.525 & 0.575 & 2.525 & 9.350 \\
\hline S12 & 2.175 & 3.800 & 7.475 & 3.300 & 19.625 & 218.650 & 0.475 & 2.500 & 7.900 \\
\hline S13 & 3.825 & 3.825 & 11.800 & 4.350 & 31.325 & 200.125 & 0.775 & 4.125 & 10.100 \\
\hline S14 & 3.050 & 8.450 & 12.225 & 4.750 & 31.450 & 231.625 & 0.825 & 3.400 & 9.975 \\
\hline S15 & 2.325 & 6.775 & 11.775 & 4.050 & 30.950 & 228.125 & 0.875 & 3.950 & 9.425 \\
\hline S16 & 1.425 & 4.500 & 7.750 & 3.725 & 22.550 & 194.675 & 0.550 & 3.525 & 9.450 \\
\hline S17 & 2.500 & 5.125 & 10.025 & 4.400 & 31.975 & 203.450 & 0.575 & 4.600 & 12.25 \\
\hline S18 & 3.125 & 6.775 & 10.675 & 4.700 & 36.300 & 145.025 & 0.525 & 4.225 & 9.550 \\
\hline S19 & 4.975 & 10.400 & 8.150 & 5.300 & 28.175 & 200.475 & 0.750 & 4.725 & 11.675 \\
\hline S20 & 2.750 & 5.000 & 6.876 & 4.600 & 29.775 & 193.175 & 0.575 & 4.050 & 10.275 \\
\hline
\end{tabular}

Table 2. Descriptive statistics parameters for the heavy metals in soil of study area.

\begin{tabular}{|c|c|c|c|c|c|c|c|c|c|c|}
\hline Metal & $\begin{array}{l}\text { Mean } \\
(\mathrm{mg} / \mathrm{kg})\end{array}$ & Median & Min. & Max. & Range & $\begin{array}{l}\text { Standard } \\
\text { Deviation }\end{array}$ & $\begin{array}{c}\text { Coefficient Of } \\
\text { Variance \% }\end{array}$ & $\begin{array}{l}\text { Standard } \\
\text { Error }\end{array}$ & $\begin{array}{c}\text { World } \\
\text { Average Data }\end{array}$ & $\begin{array}{l}\text { Dutch Soil } \\
\text { Standards }\end{array}$ \\
\hline $\mathrm{Cd}$ & 0.64 & 0.58 & 0.47 & 0.87 & 0.40 & 0.12 & 19.03 & 0.02 & 0.4 & 0.8 \\
\hline Co & 3.43 & 3.46 & 2.27 & 4.72 & 2.45 & 0.70 & 20.56 & 0.15 & 8 & 20 \\
\hline $\mathrm{Cr}$ & 11.59 & 10.50 & 7.90 & 21.22 & 13.32 & 3.13 & 27.07 & 0.70 & 70 & 100 \\
\hline $\mathrm{Cu}$ & 2.01 & 1.52 & 0.87 & 4.97 & 4.10 & 1.09 & 54.24 & 0.24 & 30 & 36 \\
\hline $\mathrm{Ni}$ & 8.96 & 8.27 & 5.57 & 12.22 & 6.65 & 2.14 & 23.97 & 0.48 & 50 & 35 \\
\hline $\mathrm{Pb}$ & 3.82 & 3.85 & 2.62 & 5.30 & 2.67 & 0.81 & 21.35 & 0.18 & 35 & 85 \\
\hline $\mathrm{Zn}$ & 5.50 & 5.06 & 2.75 & 10.40 & 7.65 & 2.05 & 37.33 & 0.45 & 90 & 140 \\
\hline $\mathrm{Fe}$ & 235.77 & 207.50 & 145.02 & 417.70 & 272.67 & 66.29 & 28.11 & 14.82 & 40,000 & - \\
\hline
\end{tabular}

Chemometric techniques provide both qualitative and quantitative information about the source of the contamination [43]. The use of one chemometric techniques alone on soil data can still lead to extremely useful information on the soil quality [44]-[48]. In this study we employed two chemometric techniques: Principal Component Analysis (PCA) and Cluster Analysis (CA).

The aims of PCA are to determine underlying information from multivariate raw data. PCA analyzes a data table representing observations described by several dependent variables, which are, in general, inter-correlated. The goal of PCA is to extract the important information as a set of uncorrelated (i.e., orthogonal) variables. These variables are called principle components, factors eigenvectors, singular vectors, or loadings. Each unit is 
also assigned a set of scores which correspond to its projection on the components. The results of the analysis are often presented with graphs plotting the projections of the units onto the components, and the loading of the variables. The importance of each component is expressed by the variance (i.e., eigenvalue) of its projection or by the proportion of the variance explained [49]. Varimax rotation was applied because the orthogonal rotation minimizes the number of variables with a high loading on each component and facilitates the interpretation of relationships and the hypothetical source of metals, lithogenic or anthropogenic [50] [51]. The multivariate statistic method of a small set of data together with other information can provide valuable insight in the context of the sources of soil pollutants [27] [52].

Cluster analysis (AC) is an exploratory data analysis for solving classification problems. Its object is to sort cases, data, or objects into groups or clusters. The resulting clusters of objects should exhibit high internal (within-cluster) homogeneity and high external (between-clusters) heterogeneity [53]. Hierarchical CA, the most common approach, starts with each case in a separate cluster and joins clusters together step by step until only one cluster remains [54]. The results of application of the cluster analysis are best described using a dendogram or binary tree. Salah et al. [55] explained in more detail this technique.

In order to study the pollution sources of the urban soil in Fallujah city by heavy metals, Pearson's correlation, PCA and CA were conducted using Statistica 7 software [56].

\section{Results and Discussion}

The descriptive statistics of the measured variables were given in Table 2. Based on mean value, the metals follow the decreasing concentration order: $\mathrm{Fe}>\mathrm{Cr}>\mathrm{Ni}>\mathrm{Zn}>\mathrm{Pb}>\mathrm{Co}>\mathrm{Cu}>\mathrm{Cd}$. For a symmetrical distribution such as normal, the mean and median are coincide at the mid-point of the distribution. The lower coefficient of variation (CV\%) of the variables suggests that the more symmetrical is the distribution. From Table 2, the mean value of $\mathrm{Pb}$, Co, and $\mathrm{Cd}$ was closer to the median values of them, and they have lower $\mathrm{CV} \%$. This result suggests that the distribution of these metals is relative homogeneous in the study area. The distribution of $\mathrm{Zn}$ and $\mathrm{Cr}$ was less symmetrical relative to distribution of $\mathrm{Pb}$, Co, and $\mathrm{Cd}$. The distribution of $\mathrm{Ni}$ and $\mathrm{Cu}$ was not symmetry. More homogeneous distribution of $\mathrm{Pb}$, $\mathrm{Co}$, and $\mathrm{Cd}$ may be attributed to non-point sources, such as automobile exhaust, manufacturing and building emissions, and urban dust blown by the wind. The asymmetrical distribution of $\mathrm{Ni}$ and $\mathrm{Cu}$ suggests point sources of contamination, such as dumping contaminated materials (paint, oil, and household cleaners), smelters and industrial workshops.

Histograms and box-plots are very useful for the rough estimation of element distribution [57] as shown in Figure 2. The concentrations of $\mathrm{Pb}$ and Co have a normal distribution in soil of the study area, $\mathrm{Zn}$ and $\mathrm{Cd}$ have an approximately normal distribution, and $\mathrm{Ni}, \mathrm{Cu}$, and $\mathrm{Cr}$ have a non-normal distribution. Parameters such as the 25th percentile, median, 75th percentile and whiskers are shown in the box-plots. In the cases of $\mathrm{Pb}, \mathrm{Co}$, and $\mathrm{Zn}$, the concentration median is symmetrical with no extreme outliers. In the cases of $\mathrm{Cd}, \mathrm{Cr}, \mathrm{Ni}$, and $\mathrm{Cu}$ the concentration median is asymmetrical with no extreme outliers.

The results of the Pearson's correlation coefficients and their significant levels $(P<0.01)$ are shown in Table 3. Generally, a correlation coefficient $>0.7$ is interpreted as a strong relationship between two parameters, whereas values between 0.5 and 0.7 represent a moderate relationship [58]. Correlation analysis provides an effective way to reveal the relationships between multiple variables and thus have been helpful for understanding the influencing factors as well as the sources of chemical components [18]. The relationship between heavy metals can provide important information on heavy metal sources and pathways [12]. The concentration of Cu showed a strong positive relationship with $\mathrm{Co}(0.70)$, and $\mathrm{Pb}$ (0.75). Geochemically, $\mathrm{Cu}$ and $\mathrm{Pb}$ are classified as chalcophile and $\mathrm{Cu}$ and $\mathrm{Co}$ as siderophile. This suggests these heavy metals may originate from a natural common source. The $\mathrm{Pb}$ concentration has a strong positive relationship with Co (0.76), and moderate with $\mathrm{Zn}(0.58)$ suggesting that these metals come from similar sources. $\mathrm{Pb}$ and $\mathrm{Zn}$ are chalcophile elements and Co is sederophile but it shows affinity for chalcophile group. Additionally, the correlations between $\mathrm{Ni}$ and $\mathrm{Cd}(0.65)$ and $\mathrm{Ni}$ and $\mathrm{Co}(0.56)$ are moderately positive. Ni and Co are classified as sederophile elements and Ni shows affinity for chalchophile group that include $\mathrm{Cd}$. The correlation between $\mathrm{Cd}$ and $\mathrm{Ni}$ indicates that both are from common source. The concentration of $\mathrm{Cr}$ showed a weak to very weak correlations with other metals suggesting that $\mathrm{Cr}$ was from different source than other metals. Cr is classified as lithophile element.

The obtained SMI values were below 100\% suggesting that the soils of study area are unpolluted with heavy metals. The spatial variation of SMI (Figure 3) reflects effect of the anthropogenic activities in the enrichment of heavy metals. The spatial distribution of heavy metals (Figure 4) was in a good agreement with that of SMI. 

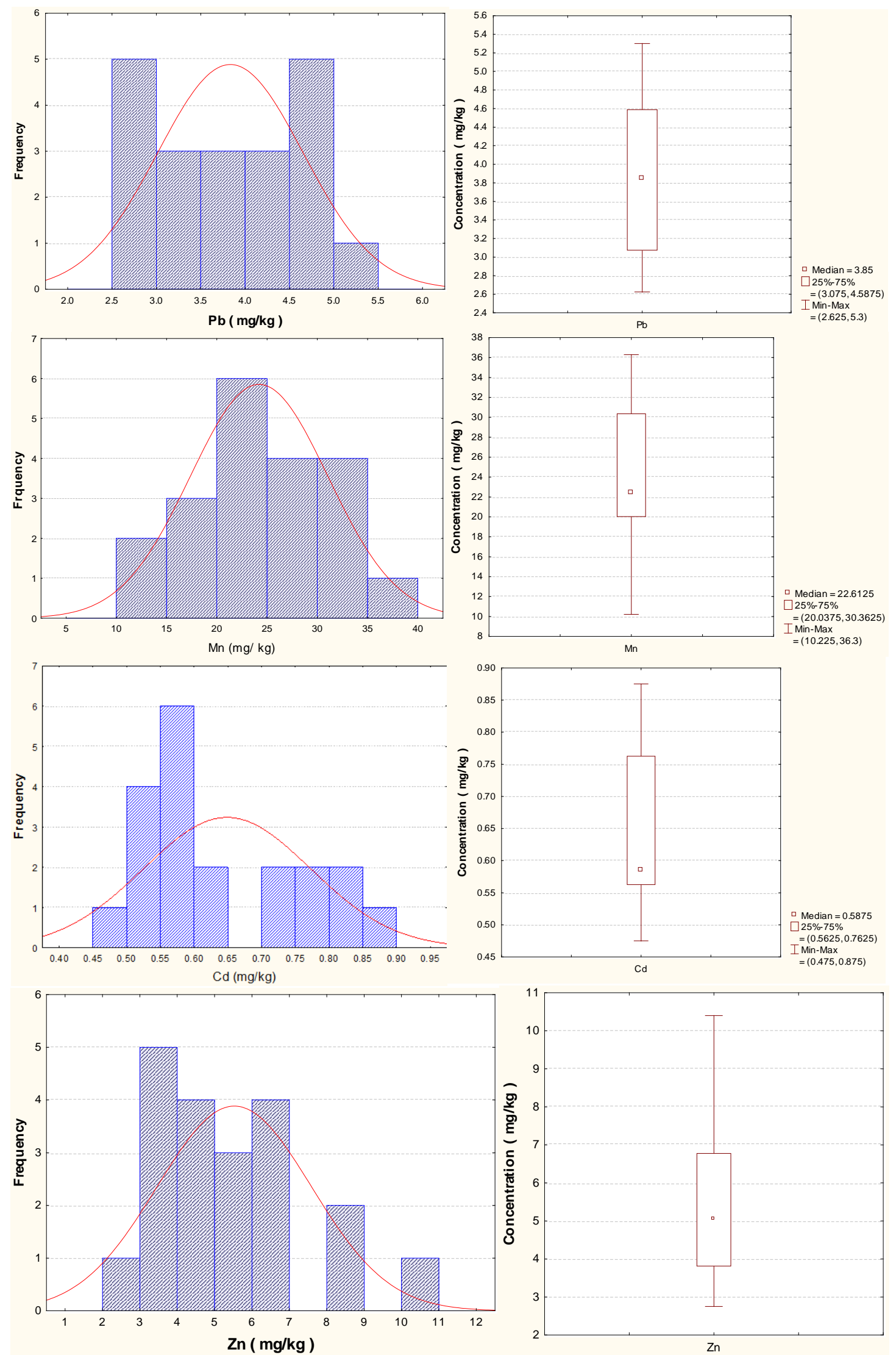

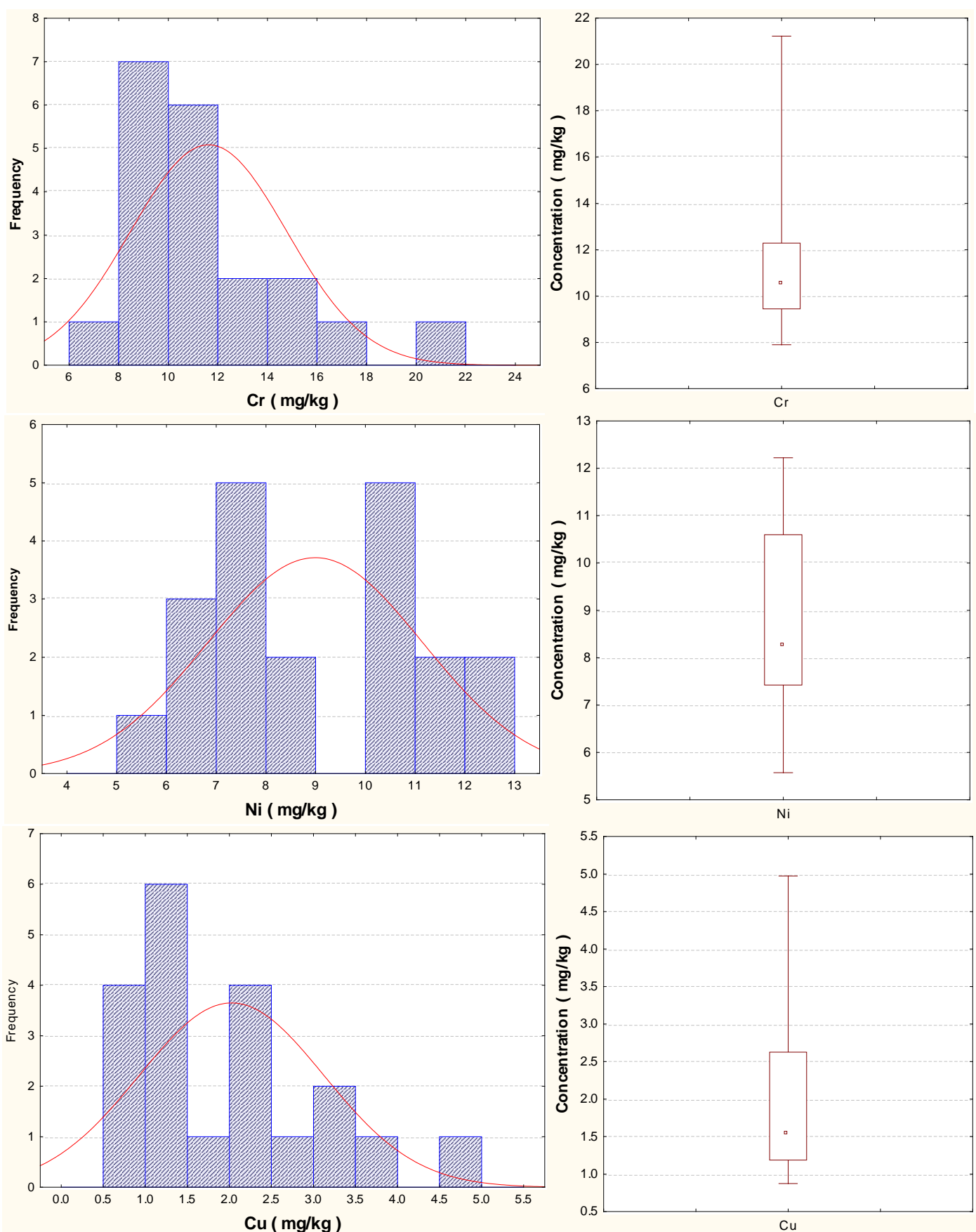

Figure 2. Histograms and box-plot of heavy metals in the soil.

This indicates that we can evaluate the heavy metals distribution depending on the soil pollution level in terms of soil metal index (SMI).

The enrichment factor (EF) was used to quantify the level of pollution and the potential anthropogenic effects in urban soils of Fallujah city. Basically, as the EF values increase, the contributions of the anthropogenic sources also increase. If an enrichment factor is greater than unity, this indicates that abundance of the heavy metals in soil may not come from the local soil background but other natural and/or anthropogenic sources in urbanized areas, including vehicle emissions, industrial discharge and other activities [59] [60]. However, enrichment factors less than 5 may be not considered significant although they are an indicator of metal accumulation, because such small enrichments may arise from differences in the composition of local soil material 


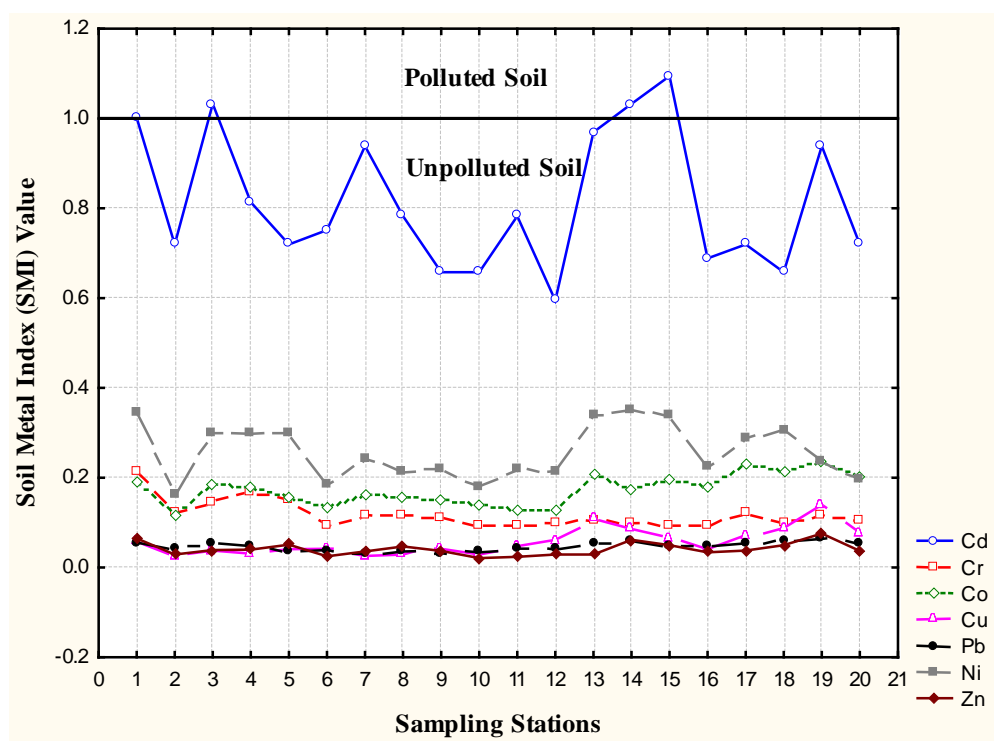

Figure 3. Spatial variation of soil metal index (SMI).

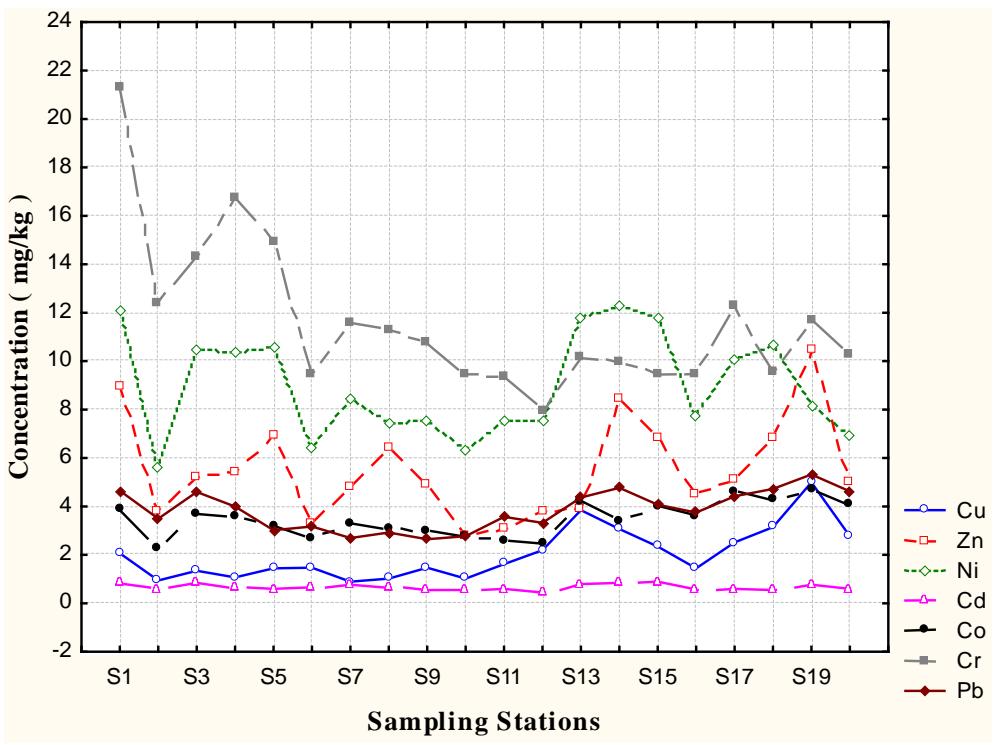

Figure 4. Spatial variation of concentrations of heavy metals in the soil.

Table 3. Pearson's correlation coefficient of heavy metals in soil samples of Fallujah City.

\begin{tabular}{cccccccc}
\hline Variable & $\mathrm{Cu}$ & $\mathrm{Zn}$ & $\mathrm{Ni}$ & $\mathrm{Cd}$ & $\mathrm{Co}$ & $\mathrm{Cr}$ & $\mathrm{Pb}$ \\
\hline $\mathrm{Cu}$ & 1.00 & & & & & & \\
$\mathrm{Zn}$ & 0.53 & 1.00 & & & & & \\
$\mathrm{Ni}$ & 0.37 & 0.54 & 1.00 & & & & \\
$\mathrm{Cd}$ & 0.29 & 0.51 & $\mathbf{0 . 6 5}$ & 1.00 & & & \\
$\mathrm{Co}$ & $\mathbf{0 . 7 0}$ & $\mathbf{0 . 5 8}$ & $\mathbf{0 . 5 6}$ & 0.41 & 1.00 & & \\
$\mathrm{Cr}$ & -0.17 & 0.43 & 0.40 & 0.33 & 0.19 & 1.00 & \\
$\mathrm{~Pb}$ & $\mathbf{0 . 7 5}$ & $\mathbf{0 . 5 8}$ & 0.53 & 0.47 & $\mathbf{0 . 7 6}$ & 0.21 & 1.00 \\
\hline
\end{tabular}

${ }^{*}$ Marked correlations are significant at $\mathrm{p}<0.01$. 
and the reference background value used in the EF calculations [14]. If the EF values are greater than 5, they are considered to be soil contamination for related metals. The mean values of enrichment factors are greater than 5 for Cd (287.13), Co (78.13), Ni (31.88), Cr (28.31), Pb (19.62), Cu (12) and Zn (10.87). The results of EF indicated that the urban soils in Fallujah city were extremely high enriched with $\mathrm{Cd}$ and Co, very high enriched with $\mathrm{Ni}$ and $\mathrm{Cr}$ and $\mathrm{Pb}, \mathrm{Cu}$ and $\mathrm{Zn}$ exhibit significant enrichment. It can be concluded that $\mathrm{Cd}$ followed by Co was the most serious enriched heavy metals in the urban soil of Fallujah. The high enrichment factor for $\mathrm{Cd}$ and $\mathrm{Pb}$ indicate the importance of industrial and traffic emission by fossil fuel and atmospheric deposition as sources of this metal. The significant sources of Co in soils are derived from the deliberate applications of Co salts or Co treated phosphate fertilizers [61]. Because of Fallujah city suffered military operations and bombing in the past years and are still being, we suggest that the military operations can be important source for enrichment heavy metals such as ( $\mathrm{Pb}, \mathrm{Cu}, \mathrm{Zn}, \mathrm{Ni})$ in the study area. The sources of the heavy metals in the battlefields and bombed cities are shells, bullets, bombs, unexploded mines, cartridge cases, damaged vehicles, leaking fuel and burning building [62]. The spatial distribution of EF values showed that high enrichment for heavy metals occurs at sampling sites (7 and 13 - 19) located in the built - up area of the old city (Figure 5). This result can be attributed to intensive anthropogenic activities in these sites.

The principal component analysis (PCA) was performed to investigate the relationship among the seven metals analyzed. The principal components with eigenvalues larger than 1 were extracted with loadings rotated for the maximum variance. Two factors were extracted, accounting for $75.315 \%$ of the total variance (Table 4). The variance of F1 and F2 was $43.110 \%$ and $32.205 \%$, respectively. Spatial representation of the two rotated components is shown in (Figure 6). Factor 1 had strong loadings on $\mathrm{Co}, \mathrm{Cu}$ and $\mathrm{Pb}$, and moderate positive loading on $\mathrm{Zn}$. Copper, $\mathrm{Pb}$ and $\mathrm{Zn}$ are chalcophile elements while $\mathrm{Co}$ is siderophile element which is primary rock forming element. Correlation analysis showed strong relationship between $\mathrm{Cu}, \mathrm{Co}$ and $\mathrm{Pb}$, and this confirmed the above result. The association of $\mathrm{Cu}, \mathrm{Pb}$, and $\mathrm{Zn}$ in $\mathrm{F} 1$ may be attributed to their lithogenic source. Factor 2 comprised $\mathrm{Cr}$ and $\mathrm{Ni}$ with high loadings and $\mathrm{Cd}$ and $\mathrm{Zn}$ with moderate loadings. The good relation between $\mathrm{Ni}$ and $\mathrm{Cd}(0.65)$ confirmed this result. As shown in (Table 4) Zn was distributed in F1 and F2. The association of $\mathrm{Cr}, \mathrm{Ni}$, and $\mathrm{Cd}$ in $\mathrm{F} 2$ suggests that these metal come from mixed sources.

Researches indicates that $\mathrm{Cr}$ and $\mathrm{Ni}$ come from the same mineral, and they always associate with each other [63] [64]. The possible sources of $\mathrm{Ni}$ and $\mathrm{Cd}$ in the soil of study area are agricultural fertilizers, residues from combustion of fossil fuels and waste water.

The dendrogram of the hierarchical cluster analysis of metal contents in the study area is shown in (Figure 7). Two distinct clusters were identified. The first cluster (I) contained $\mathrm{Cu}, \mathrm{Co}, \mathrm{Pb}, \mathrm{Cd}$, and $\mathrm{Zn}$. The second cluster (II) included $\mathrm{Ni}$ and $\mathrm{Cr}$. The elements of cluster I are considered to be mixed in origin. $\mathrm{Cu}, \mathrm{Zn}$ and $\mathrm{Pb}$ may be

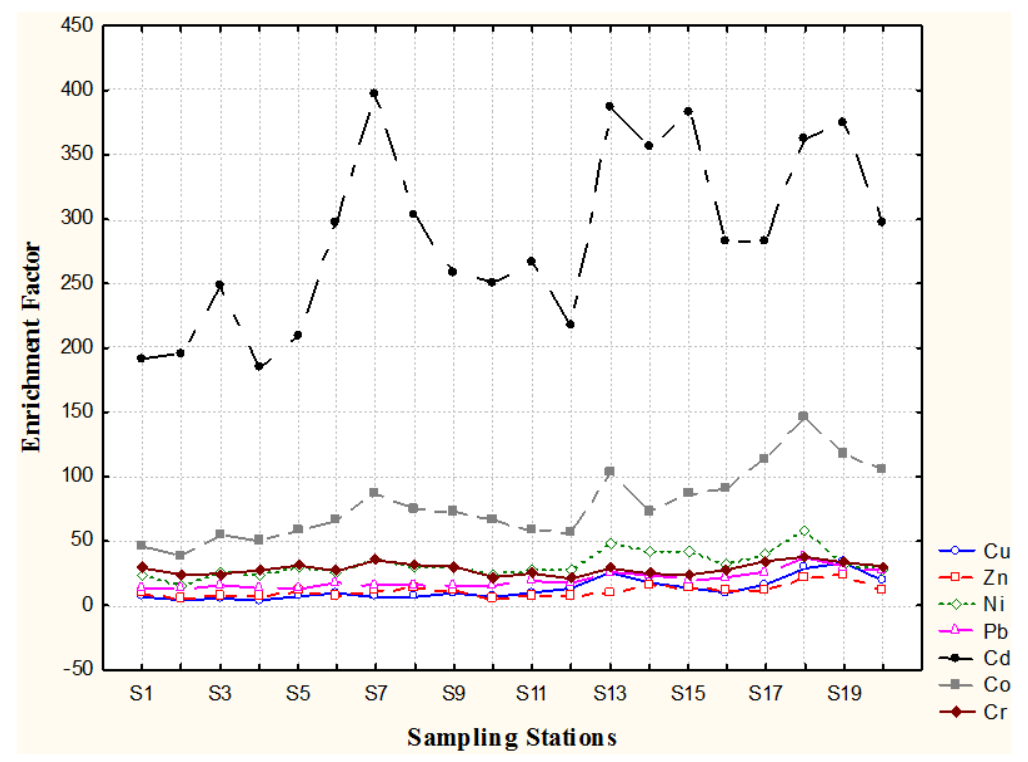

Figure 5. Spatial variation of enrichment factor of heavy metals of the urban soil in Fallujah city. 


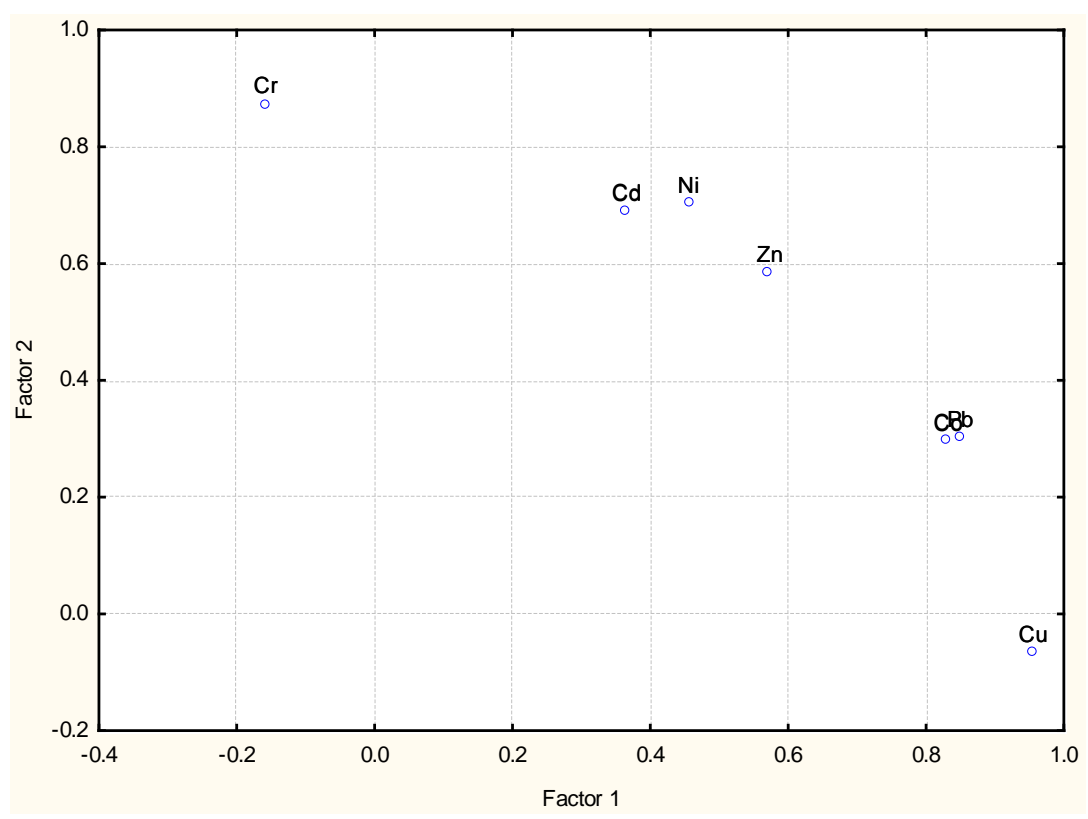

Figure 6. Principal component analysis loading parts for the rotated components.

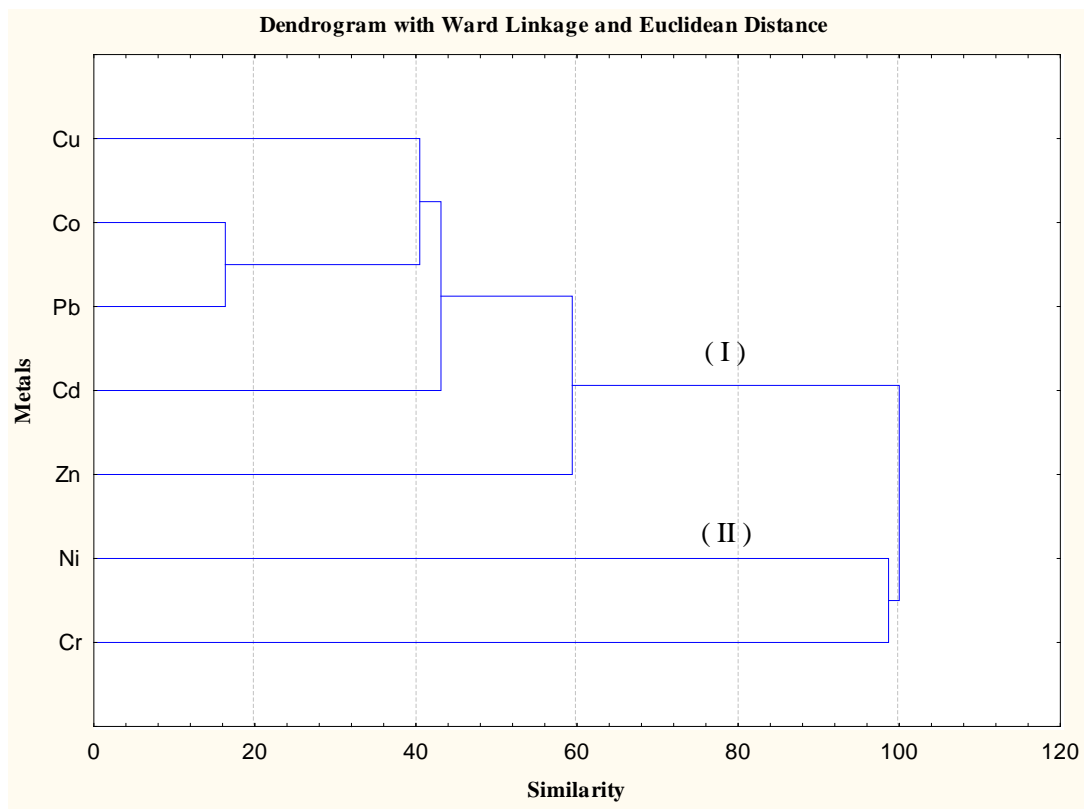

Figure 7. Dendrogram of the cluster analysis of the urban soil in Fallujah city.

the result of weathering of sulfide minerals such as galena and sphalerite. The elements of cluster II are of lithogenic origin. The results of cluster analysis confirmed the results of PCA except for Cd. Cluster analysis is often used to confirm the results of principle component analysis [45] [48] [65] [66].

The groupings from hierarchical cluster analysis showed sampling stations ordered in two main clusters, I and II (Figure 8). The cluster I includes S1 only. High concentrations of heavy metals were reported in this station as shown in Figure 4. Cluster II contained other stations (S2-S19). The cluster II was classified into three groups: A, B, and C. The group A includes (S3-S5 and S18), group B (S7, S13-S15, S17, S20), and group C (S2, S6, S8-S12, S16). The spatial distribution of heavy metals concentrations confirmed these results (Figure 4). These findings indicate that members of each group were distributed based on whether the sources of enrichment were point or nonpoint. 


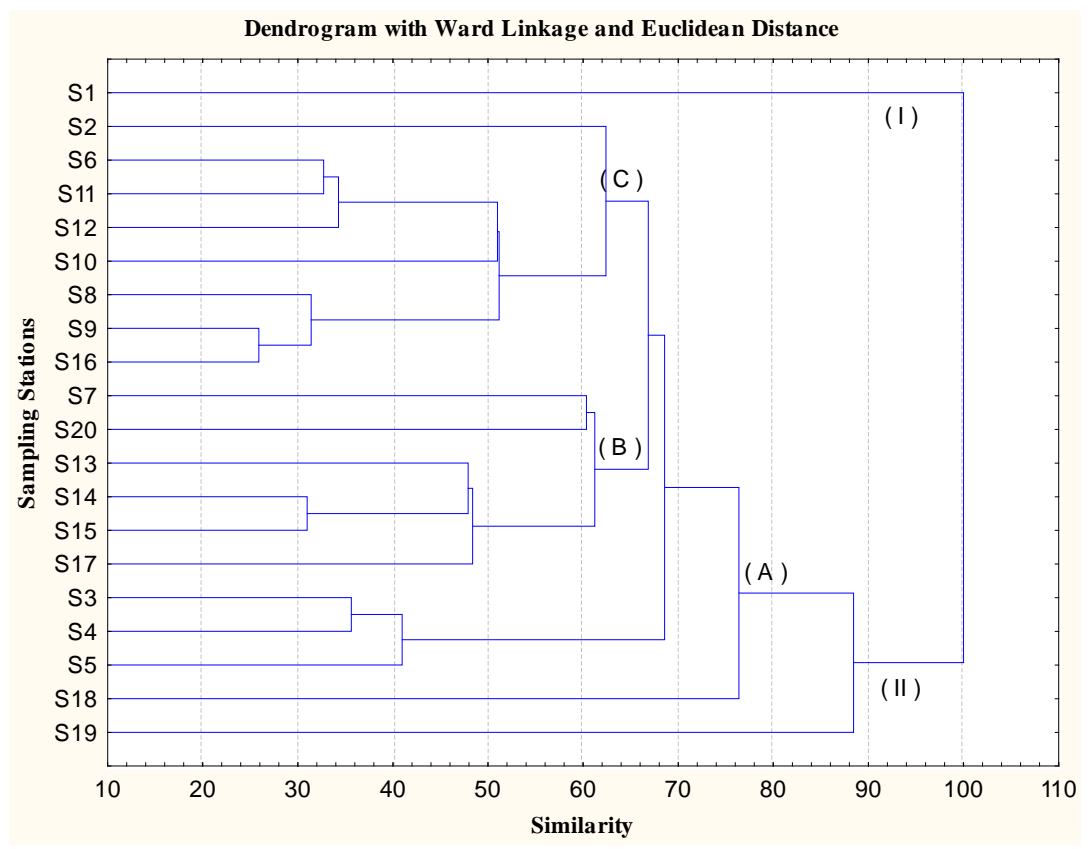

Figure 8. Dendrogram of spatial clustering of sampling stations.

Table 4. Factor loadings (varimax rotation) on heavy metals in soil samples in Fallujah city.

\begin{tabular}{ccc}
\hline Element & Factor 1 & Factor 2 \\
\hline Cd & 0.365 & $\mathbf{0 . 6 8 9}$ \\
$\mathbf{C o}$ & $\mathbf{0 . 8 3 1}$ & 0.295 \\
$\mathbf{C r}$ & -0.157 & $\mathbf{0 . 8 7 3}$ \\
$\mathbf{C u}$ & $\mathbf{0 . 9 5 4}$ & -0.067 \\
$\mathbf{N i}$ & 0.455 & $\mathbf{0 . 7 0 1}$ \\
$\mathbf{P b}$ & $\mathbf{0 . 8 4 8}$ & 0.301 \\
$\mathbf{Z n}$ & 0.572 & 0.584 \\
Eigenvalue & 3.017 & 2.254 \\
Variance explained \% & 43.110 & 32.205 \\
Cumulative variance \% & 43.110 & 75.315 \\
\hline
\end{tabular}

\section{Conclusions}

From the obtained results, we concluded the following:

1) According to the soil metal index, the urban soils of Fallujah city is unpolluted.

2) The industrial and traffic emission by fossil fuel, atmospheric deposition, and the military operations and bombing caused significant to extremely high enrichments of heavy metals, such as $\mathrm{Cd}, \mathrm{Co}, \mathrm{Ni}, \mathrm{Cr}, \mathrm{Pb}, \mathrm{Cu}$, and Zn.

3) The moderate to strong positive correlations among $\mathrm{Cd}, \mathrm{Co}, \mathrm{Cu}, \mathrm{Cr}, \mathrm{Ni}, \mathrm{Pb}$, and $\mathrm{Zn}$ suggest that these metals have common sources.

4) The results of a PCA performed on seven heavy metals confirmed by the cluster analysis (CA), identified two factors controlling their variability in urban soil of Fallujah city. The variability of $\mathrm{Cu}, \mathrm{Co}, \mathrm{Pb}$, and $\mathrm{Zn}$ is associated in the same factor and is controlled by lithogenic origin. The variability of $\mathrm{Cr}, \mathrm{Ni}$, and $\mathrm{Cd}$ is controlled by mixed origin (lithogenic and anthropogenic).

5) This study also reconfirms that chemometeric techniques such as PCA and CA can be used to identify sources of soil pollution. 


\section{References}

[1] Bockheim, J. (1974) Nature and Properties of Highly Distributed Urban Soils, Philadelphia, Pennsylvania. Paper Presented before Div. S-5, Soil Science Society of America, Chicago.

[2] Kabata-Pendias, A. and Pendias, H. (1992) Trace Elements in Soils and Plants. 2nd Edition, CRC Press, Boca Raton.

[3] Tiller, K. (1992) Urban Soil Contamination in Australia. Australia Journal of Soil Research, 30, 937-957. http://dx.doi.org/10.1071/SR9920937

[4] Bretzel, F. and Calderisi, M. (2006) Metal Contamination in Urban Soils of Coastal Tuscany (Italy). Environmental Monitoring and Assessment, 118, 319-335. http://dx.doi.org/10.1007/s10661-006-1495-5

[5] Callender, E. and Rice, K. (2000) The Urban Environment Gradient: Anthropogenic Influences on the Spatial and Temporal Distributions of Lead and Zinc in sediments. Environmental Science and Technology, 34, 232-238. http://dx.doi.org/10.1021/es990380s

[6] Grzebisz, W., Ciesla, L., Komisarek, J. and Potarzycki, J. (2002) Geochemical Assessment of Heavy Metals Pollution of Urban Soils. Polish Journal of Environmental Studies, 11, 493-499.

[7] Bacon, J., Berrow, M. and Shand, C. (1992) Isotopic Composition as an Indicator of Origin of Lead Accumulations in Surface Soils. International Journal of Environmental Analytical Chemistry, 46, 71-76. http://dx.doi.org/10.1080/03067319208026998

[8] Škrbic, B. and Đuriśić-Mladenović, N. (2010) Chemometric Interpretation of Heavy Metal Patterns in Soils Worldwide. Chemosphere, 80, 1360-1369. http://dx.doi.org/10.1016/j.chemosphere.2010.06.010

[9] Vidovic, M., Sadibasic, A., Cupic, S. and Lausevic, M. (2005) Cd and Zn in Atmospheric Deposit, Soil, Wheat and Milk. Environmental Research, 97, 26-31. http://dx.doi.org/10.1016/j.envres.2004.05.008

[10] Carrizales, L., Razo, I., Tellez-Hernandez, J., Torres-Nerio, R. Batres, L., Cubillas, A. and Diaz-Barriga, F. (2006) Exposure to Arsenic and Lead of Children Living Near a Copper-Smelter in San Luis Potosi, Mexico: Importance of Soil Contamination for Exposure of Children. Environmental research, 101, 1-10. http://dx.doi.org/10.1016/j.envres.2005.07.010

[11] De Miguel, E., Iribarren, I., Chacon, E., Ordonez, A. and Chalesworth, S. (2006) Risk-Based Evaluation of Exposure of Children to Trace Elements in Playgrounds in Madrid (Spain). Chemosphere, 66, 505-513. http://dx.doi.org/10.1016/j.chemosphere.2006.05.065

[12] Manata, D., Angelone, M., Bellanca, A., Neri, R. and Sprovieri, M. (2002) Heavy Metals in Urban Soils: A Case Study from the City of Palermo (Sicily). Science of the Total Environment, 300, 229-243. http://dx.doi.org/10.1016/S0048-9697(02)00273-5

[13] Maas, S., Scheifler, R., Benslama, M., Crini, N., Lucot, E., Brahmia, Z., Benyacoub, S. and Giraudoux, P. (2010) Spatial Distribution of Heavy Metal Concentrations in Urban, Suburban and Agricultural Soils in a Mediterranean City of Algeria. Environmental Pollution, 158, 2294-2301. http://dx.doi.org/10.1016/j.envpol.2010.02.001

[14] Wan, S. and Qin, Y. (2007) Some Characteristics of the Distribution of Heavy Metals in Urban Topsoil of Xuzhou, China. Environmental Geochemistry and Health, 29, 11-19. http://dx.doi.org/10.1007/s10653-006-9052-2

[15] Tume, P., Bech, J., Sepulveda, B., Tume, L. and Bech, J. (2008) Concentrations of Heavy Metals in Urban Soils of Talcahuano (Chile): A Preliminary Study. Environmental Monitoring and Assessment, 140, 91-98. http://dx.doi.org/10.1007/s10661-007-9850-8

[16] Ali, S. and Malik, R. (2011) Spatial Distribution of Metals in Top Soils of Islamabad City, Pakistan. Environmental Monitoring and Assessment, 172, 1-16. http://dx.doi.org/10.1007/s10661-010-1314-X

[17] Guo, G., Wu, F., Xie, F. and Zhang, R. (2012) Spatial Distribution and Pollution Assessment of Heavy Metals in Urban Soils from Southwest China. Journal of Environmental Sciences, 24, 410-418. http://dx.doi.org/10.1016/S1001-0742(11)60762-6

[18] Li, X., Liu, L., Wang, Y., Luo, G., Chen, X., Yang, X., Hall, M., Guo, R., Wang, H., Cui, J. and He, X. (2013) Heavy Metal Contamination of Urban Soil in an Old Industrial City (Shenyang) in Northeast China. Geoderma, 192, 50-58. http://dx.doi.org/10.1016/j.geoderma.2012.08.011

[19] Cai, Q., Mo, C., Li, H., Lü, H., Zeng, Q., Li, Y. and Wu, X. (2013) Heavy Metal Contamination of Urban Soils and Dusts in Guangzhou, South China. Environmental Monitoring and Assessment, 185, 1095-1106. http://dx.doi.org/10.1007/s10661-012-2617-x

[20] Simon, E., Vidic, A., Braun, M., Fábián, I. and Tóthmérész, B. (2013) Trace Element Concentrations in Soils along Urbanization Gradients in the City of Wien, Austria. Environmental Science \& Pollution Research, 20, 917-924. http://dx.doi.org/10.1007/s11356-012-1091-x

[21] Al Obaidy, A. and Al Mashhadi, A. (2013) Heavy Metal Contaminations in Urban Soil within Baghdad City, Iraq. Journal of Environmental Protection, 4, 72-82. http://dx.doi.org/10.4236/jep.2013.41008 
[22] Salah, E., Turki, A. and Noori, S. (2013) Heavy Metals Concentration in Urban Soils of Fallujah City, Iraq. Journal of Environment and Earth Science, 3, 100-112.

[23] Krami, L., Amiri, F., Sefiyanian, A., Shariff, A., Tabatabaie, T. and Pradhan, B. (2013) Spatial Patterns of Heavy Metals in Soil under Different Geological Structures and Land Uses for Assessing Metal Enrichments. Environmental Monitoring and Assessment, 185, 9871-9888. http://dx.doi.org/10.1007/s10661-013-3298-9

[24] Hani, A., Sinaei, N. and Gholami, A. (2014) Spatial Variability of Heavy Metals in the Soils of Ahwaz Using Geostatistical Methods. International Journal of Environmental Science and Development, 5, 294-298. http://dx.doi.org/10.7763/IJESD.2014.V5.495

[25] Mostert, M., Ayoko, G. and Kokot, S. (2010). Application of Chemometrics to Analysis of Soil Pollutants. Trends in Analytical Chemistry, 29, 430-445. http://dx.doi.org/10.1016/j.trac.2010.02.009

[26] Ali, H. (2007) Heavy Metals Concentrations in Surface Soils of the Haweja Area South Western of Kirkuk, Iraq. Journal of Kirkuk University-Scientific Studies, 2, 35-48.

[27] Zhou, J., Ma, D., Pan, J., Nie, W. and Wu, K. (2008) Application of Multivariate Statistical Approach to Identify Heavy Metals Sources in Sediments and Waters: A Case Study in Yangzhong, China. Environmental Geology, 54, 373-380. http://dx.doi.org/10.1007/s00254-007-0824-5

[28] Kř̌rbek, B., Majer, V., Veselovsky, F. and Nyambe, I. (2010) Discrimination of Lithologenic and Anthropogenic Sources of Metals and Sulphur in Soils of the Central-Northern Part of the Zambian Copperbelt Mining District: A Topsoil vs. Subsurface Soil Concept. Journal of geochemical Exploration, 104, 69-86. http://dx.doi.org/10.1016/j.gexplo.2009.12.005

[29] Moura, M., Moita, G. and Neto, J. (2010) Analysis and Assessment of Heavy Metals in Urban Surface Soils of Teresina, Piauí State, Brazil: A Study Based on Multivariate Analysis. Comunicata Scientia, 1, 120-127.

[30] Yaylah-Abanuz, G. (2011) Heavy Metal Contamination of Surface Soil around Gebze Industrial Area. Turkey. Microchemistry Journal, 99, 82-92. http://dx.doi.org/10.1016/j.microc.2011.04.004

[31] Bingöl, D., Ay, Ü., Bozbaş, S. and Uzgören, N. (2013) Chemometric Evaluation of the Heavy Metals Distribution in Waters from Dilvasi Region in Kocaeli, Turkey. Marine Pollution Bulletin, 68, 134-139. http://dx.doi.org/10.1016/j.marpolbul.2012.12.006

[32] Li, X. and Feng, L. (2012) Geostatistical Analysis and Fractionation of Heavy Metals in Urban Soils from Industrial District in Weinan, NW China. Environmental Earth Sciences, 67, 2129-2140. http://dx.doi.org/10.1007/s12665-012-1653-8

[33] Soffianian, A., Madani, E. and Arabi, M. (2014) Risk Assessment of Heavy Metal Soil Pollution through Principal Components Analysis and False Color Composition in Hamadan Province, Iran. Environmental System Research, $3,3$. http://dx.doi.org/10.1186/2193-2697-3-3

[34] Salah, E., Zaidan, T. and Al-Rawi, A. (2012) Assessment of Heavy Metals Pollution in the Sediments of Euphrates river, Iraq. Journal of Water Resource and Protection, 4, 1009-1023. http://dx.doi.org/10.4236/jwarp.2012.412117

[35] Dutch Standards (2000) Circular on Target Values and Intervention Values for Remediation. Dutch Ministry of Housing, Spatial Planning and Environment, Netherlands Government Gazette.

[36] Feng, H., Han, X., Zhang, W. and Yu, L. (2004) A Preliminary Study of Heavy Metal Contamination in Yangtze River Intertidal Zone Due to Urbanization. Marine Pollution Bulletin, 49, 910-915. http://dx.doi.org/10.1016/j.marpolbul.2004.06.014

[37] Cato, I. (1977) Recent Sedimentological and Geochemical Conditions and Pollution Problems in Two Marine Areas in Southwestern Sweden. Striae, 6, 1-150.

[38] Choi, K., Kim, S., Hong, G. and Chon, H. (2012) Distribution of Heavy Metals in the Sediments of South Korean Harbors. Environmental Geochemical Health, 34, 71-82. http://dx.doi.org/10.1007/s10653-011-9413-3

[39] Sinex, S. and Helz, G. (1981) Regional Geochemistry of Trace Elements in Chesapeak Bay Sediments. Environmental Geology, 3, 315-323. http://dx.doi.org/10.1007/BF02473521

[40] Bowen, H. (1979) Environmental Chemistry of the Elements. Academic Press, London.

[41] Tippie, V. (1984) An Environmental Characterization of Chesa-Peak Bay and a Framework for Action. In: Kennedy, V., Ed., The Estuary as a Filter, Academic Press, New York, 467-487. http://dx.doi.org/10.1016/B978-0-12-405070-9.50028-1

[42] Mmolawa, K., Likuku, A. and Gaboutloeloe, G. (2011) Assessment of Heavy Metal Pollution in Soils along Roadside Areas in Botswana. African Journal of Environmental Science and Technology, 5, 186-196.

[43] Zhou, F., Guo, H. and Liu, L. (2007) Quantitative Identification and Source Apportionment of Anthropogenic Heavy Metals in Marine Sediments of Hong Kong. Environmental Geology, 53, 295-305. http://dx.doi.org/10.1007/s00254-007-0644-7 
[44] Chen, T., Wang, J., Zhou, H. and Wong, M. (1996) Assessment of Trace Metal Distribution and Contamination in Surface Soils of Hong Kong. Environmental Pollution, 96, 61-68. http://dx.doi.org/10.1016/S0269-7491(97)00003-1

[45] Carlosena, A., Andrade, J. and Prada, D. (1998) Searching For Heavy Metals Grouping Roadside Soils as a Function of Motorized Traffic Influence. Talanta, 47, 753-767. http://dx.doi.org/10.1016/S0039-9140(98)00117-9

[46] Kokot, S., Grigg, M., Panayiotou, H. and Phuong, T. (1999) Data Interpretation by Some Common Chemometrics Methods. Electroanalysis, 10, 1081-1086. http://dx.doi.org/10.1002/(SICI)1521-4109(199811)10:16<1081::AID-ELAN1081>3.0.CO;2-X

[47] Chen, T., Zheng, Y., Lei, M., Huang, Z., Wu, H., Chen, H., Fan, K., Yu, K., Wu, X. and Tian, Q. (2005) Assessment of Heavy Metal Pollution in Surface Soils of Urban Parks in Beijing, China. Chemosphere, 60, 542-551. http://dx.doi.org/10.1016/j.chemosphere.2004.12.072

[48] Heinrich, A. (2007) The Application of Multivariate Statistical Methods for Evaluation of Soil Profiles. Journal of Soil and Sediments, 7, 45-52. http://dx.doi.org/10.1065/jss2006.11.193

[49] Abdi, H. (2003) Multivariate Analysis. In: Lewis-Beck, M., Bryman, A. and Futing, T., Eds., Encyclopedia of Social Sciences Research Methods, Sage, Thousand Oaks.

[50] Acosta, J., Faz, A., Martinez-Martinez, S., Zomoza, R., Carmona, D. and Kabas, S. (2011) Multivariate Statistical and GIS-Based Approach to Evaluate Heavy Metals Behavior in Mine Sites for Future Reclamation. Journal of Geochemical Exploration, 109, 8-17. http://dx.doi.org/10.1016/j.gexplo.2011.01.004

[51] Bini, C., Sartori, G., Wahsha, M. and Fontana, S. (2011) Background Levels of Trace Elements and Soil Geochemistry at Regional Level in NE Italy. Journal of Geochemical Exploration, 109, 125-133. http://dx.doi.org/10.1016/j.gexplo.2010.07.008

[52] Boruvka, L., Vacek, O. and Jehlicka, J. (2005) Principal Component Analysis as a Tool to Indicate the Origin of Potentially Toxic Elements in Soils. Geoderma, 128, 289-300. http://dx.doi.org/10.1016/j.geoderma.2005.04.010

[53] McGarial, K., Cushman, S. and Stafford, S. (2000) Multivariate Statistics for Wildlife and Ecology Research. Springer, New York. http://dx.doi.org/10.1007/978-1-4612-1288-1

[54] Mckenna, G. (2003) An Enhanced Cluster Analysis Program with Bootstrap Significant Testing for Ecological Community Analysis. Environmental Modeling and Software, 18, 205-220. http://dx.doi.org/10.1016/S1364-8152(02)00094-4

[55] Salah, E., Turki, A. and Al-Othman, E. (2012) Assessment of Water Quality of Euphrates River Using Cluster Analysis. Journal of Environmental Protection, 3, 1269-1273. http://dx.doi.org/10.4236/jep.2012.312180

[56] Stat. Soft. Inc. (2007) STATISTICA (Data Analysis Software System) Version 8. www.statsoft.com

[57] Mrvić, V., Kostić-Kravljanac, L., Sikirić, B., Perović, V. and Niloloski, M. (2011) Pedogeochemical Mapping and Background Limit of Trace Elements in Soils of Branicevo Province (Serbia). Journal of Geochemical Exploration, 109, 18-25. http://dx.doi.org/10.1016/j.gexplo.2010.09.005

[58] Pam, E., Akiti, T., Osae, S., Ganyaglo, S. and Gibrilla, A. (2011) Multivariate Cluster Analysis of Some Major and Trace Elements Distribution in an Unsaturated Zone Profile, Densu River Basin, Ghana. African Journal of Environmental Science and Technology, 5, 155-167.

[59] Gibson, M. and Farmer, J. (1986) Multi-Step Chemical Extraction of Heavy Metals from Urban Soils. Environmental Pollution, 11, 117-135. http://dx.doi.org/10.1016/0143-148x(86)90039-x

[60] Thornton, I. (1991) Metal Contamination of Soils in Urban Areas. In: Bullock, P. and Gregory, P.J., Eds., Soils in the Urban Environment, Blackwell, Oxford, 47-75. http://dx.doi.org/10.1002/9781444310603.ch4

[61] Smith, K. and Paterson, J. (1995) Manganese and Cobalt. In: Alloway, B.J., Ed., Heavy Metals in Soils, Champan \& Hall, Glasgow, 224-244. http://dx.doi.org/10.1007/978-94-011-1344-1_10

[62] Alloway, B.J. (2012) Sources of Heavy Metals and Metalloids in Soils. In: Alloway. B.J., Ed., Heavy Metals in Soils: Trace Metals and Metalloids in Soils and Their Bioavailability, Environmental Pollution, Vol. 22, Springer, Dordrecht, 11-50.

[63] Zheng, Y., Cheng, H., Cheng, T., Zheng, G., Wu, H. and Zhou, J. (2003) Spatial Distribution Patterns of Cr and Ni in Soils of Beijing. Quaternary Sciences, 23, 436-445.

[64] Zheng, Y., Cheng, T., Zheng, G., Huange, Z. and Lou, J. (2005) Chromium and Nickel Accumulations in Soils under Different Land Use in Beijing municipality. Resources Science, 27, 162-166.

[65] Facchinelli, A., Sacchi, E. and Mallen, L. (2001) Multivariate Statistical and GIS-Based Approach to Identify Heavy Metal Sources in Soils. Environmental Pollution, 114, 313-324. http://dx.doi.org/10.1016/S0269-7491(00)00243-8

[66] Wang, X., Qin, Y. and Sang, S. (2005) Accumulation and Sources of Heavy Metals in Urban Topsoils: A Case Study from City of Xuzhou, China. Environmental Geology, 48, 101-107. http://dx.doi.org/10.1007/s00254-005-1270-X 